\title{
The prospects of development of the citrus production in the Neretva valley in the context of contemporary tendencies
}

\author{
Perspektive razvoja hrvatskog agrumarstva u dolini Neretve \\ u kontekstu suvremenih tendencija
}

Ivana Paladin Soče, D. Ivić, Mara Marić

\begin{abstract}
In most countries of the world where citrus fruits are grown, including Croatia, several viruses and virus-like agents exist limiting the production and sale of citrus fruits. The most common among them is Citrus tristeza virus (CTV) which causes a decrease in tree fertility and lushness. The aim of this paper is to illustrate the large scale of consequences caused by the CTV in Spain during the $20^{\text {th }}$ century. More than 44 million citrus trees grafted on sour orange (Citrus aurantim L) rootstock sourhad decayed over a period of 10 years due to the intensing spread of CTV. The approaches that addressed the problem of infection of large citrus growing areas in Spain will be presented. Based on the experience in Spain, this paper will show the possibilities of implementing systematic expert measures which would eradicate or minimize the presence of CTV in the area of the Neretva valley, the most important citrus growing area in Croatia.

A large number of researches have been carried out on the presence and the outspread of CTV in the Neretva Valley from 2005 to 2019. During this period, the highest percentage of virus outspread was observed in 2006, when CTV was detected in $80 \%$ of the collected samples. The virus was regularly detected in the Neretva valley in all the years the research was conducted.

The problem of CTV has been present for many years and the pathogen is still spreading, which indicates the need to take some measures to prevent this continuous spreading. Among the most important and effective measures is the control of viral diseases in the propagation materials and the mother blocks and planting virus-free plants in accordance with the provisions of the Ordinance on placing reproductive planting material and seedlings intended for fruit production on the market (OG 9/17, 39/20), which contain European Union Directives 2008/90 / EC, 2014/96 / EU, and 2014/98 / EU.
\end{abstract}

Key words: citrus fruits, Citrus tristeza virus, Spain, eradication, Neretva valley 
Ivana Paladin Soče i sur.: The prospects of development of the citrus production in the Neretva valley in the context of contemporary tendencies

\section{SAŽETAK}

U većini zemalja svijeta gdje se uzgajaju agrumi, pa tako i u Hrvatskoj, prisutni su pojedini štetni organizmi koji mogu ograničavati proizvodnju i prodaju agruma. Među njima, najpoznatiji je Citrus tristeza virus (CTV) koji uzrokuje smanjenje rodnosti i bujnosti stabala. Cilj ovog rada je na primjeru Śpanjolske prikazati velike razmjere posljedica koje je prouzrokovao CTV tijekom 20. stoljeća. Zbog intenzivnog širenja virusa unutar plantažnih nasada u razdoblju od 10 godina propalo je više od 44 milijuna stabala agruma nacijepljenih na podlogu gorke naranče (Citrus aurantim L.). Prikazati će se pristupi kojima su se u Španjolskoj rješavali problemi zaraze velikih uzgojnih područja agruma. Temeljem španjolskih iskustava prikazati će se mogućnosti provođenja sustavnih stručnih mjera na područje doline Neretve, najvažnijeg uzgojnog područja agruma u Hrvatskoj, kojima bi se širenje CTV-a svelo na najmanju moguću mjeru.

Na području doline Neretve od 2005. do 2019. godine proveden je veći broj istraživanja prisutnosti i raširenosti CTV-a. Tijekom tog razdoblja, najveći postotak raširenosti virusa zabilježen je 2006. godine, kada je CTV utvrđen u 80 \% uzoraka. Virus je redovito utvrđen u dolini Neretve u svim godinama u kojima su istraživanja provedena.

Problem CTV-a je prisutan već dugi niz godina i patogen se i dalje širi, što nam ukazuje na potrebu poduzimanja mjera sprječavanja njegovog širenja. Među najvažnijim stručnim mjerama je kontrola prisutnosti virusa u sadnom materijalu i sadnja zdravog sadnog materijala prema odredbama Pravilnika o stavljanju na tržište reprodukcijskog sadnog materijala i sadnica namijenjenih za proizvodnju voća (NN 9/17, 39/20) u kojem su sadržane direktive Europske unije 2008/90/EZ, 2014/96/EU, i 2014/98/EU.

Ključne riječi: agrumi, Citrus tristeza virus, Španjolska, eradikacija, dolina Neretve

\section{INTRODUCTION}

The most suitable growing area for citrus in the world is between $20^{\circ}$ and $40^{\circ}$ north latitude, while in Croatia citrus fruits are cultivated between $42^{\circ}$ and $44^{\circ}$ north latitude which is one of the most northern citrus growing areas in the world (Bakarić, 1983).

The commercial cultivation of citrus fruits in Croatia began in the early $20^{\text {th }}$ century. The Unshiu mandarin (Citrus unshiu Swingle) was first mentioned by Mato Bobanović (1923) in his work entitled "Neke južne culture" (Some Southern Cultures) which today represents the main commercial culture of citrus fruits in the Republic of Croatia (Kaleb, 2014). The Unshiu mandarin is a collection of many Japanese varieties and clones that are genetically prone to 
Ivana Paladin Soče i sur.: The prospects of development of the citrus production in the Neretva valley in the context of contemporary tendencies

numerous mutations and changes (Bakarić, 1983). The most represented varieties in the Neretva valley in the plantations of Unshiu mandarins are Kawano Wase, Chahara, Zorica rana and Owari (Marić and Paladin, 2017).

Over the last few years, and due to its quarantine status, Citrus tristeza virus (CTV) has been considered a problem in the production of CAC (Conformitas Agraria Communitatis) planting material, so far the only category used to produce citrus reproductive material. Within this category, diseases and pests are identified by visual inspection. On the other hand, the material produced under the certification scheme, i.e. high-grade planting material, is subjected to successive testing and stored in separate facilities (Ivić and Fazinić, 2011). Such citrus planting material is currently in the process of being developed in Croatia as a guarantee of sanitary status and variety of the species during the commercial propagation process.

Over the last few years, it has become a common practice for more economically viable nurseries to purchase virus-free seedlings as well as certified buds for grafting from other Mediterranean nurseries (Spain, France, Italy), indicating that there is an awareness of the need to grow high-grade virus-free seedlings.

Accordingly, a certification scheme or nurseries of high-grade seedlings is in the process of being established, therefore, it is expected that nurseries will start applying this process and successively, replace the old production plantations with new high-grade virus-free seedlings. Therefore, in this paper, the case of Spain is taken as a comparative example in which this process of establishing high-grade stock nurseries or production plantations that followed was conducted. This process, as consequence of the CTV infection, was started and completed in the mid- $20^{\text {th }}$ century.

This CTV viral pathogen, and depending on the scion-root stock combinations, may cause a weak development, reduced productivity and total decay of plants. CTV is graft-transmissible from infected to healthy plants, while in nature it spreads semi-persistently by aphid vectors, such as Toxoptera citricida, T. aurantii, Aphis gossypii and A. spiraecola.

This virus is considered the most harmful citrus pathogen worldwide due to epidemic events throughout history that significantly affected citrus cultivation. Most countries that are seriously involved in the production of citrus fruits have been able to address this problem through a systematic approach. At the institutional level, important steps have been taken in the Republic of Croatia to address this challenge. 
Ivana Paladin Soče i sur.: The prospects of development of the citrus production in the Neretva valley in the context of contemporary tendencies

\section{CITRUS TRISTEZA VIRUS}

Citrus tristeza virus (CTV) is a viral speices of the genus Closterovirus, family Closteroviridae that can affect all species, cultivars or hybrids of the Citrus genus (Lee and Bar-Joseph, 2000). The only natural host that does not belong to the citrus and related species and on which CTV can multiply is Passiflora spp. (Müller i sur., 1974). It is assumed that CTV first appeared in the early 19th century in Southeast Asia region and the Malaysian archipelago (Moreno et al., 2008), where it still resides in tolerant cultivars that propagate vegetative through grafting (Wubshet and Amare, 2019).

CTV began to spread in the late 19th century with the flourishing of maritime traffic by which citrus seedlings and exotic species were traded for the needs of collections and assortment of botanical gardens (Roistacher, 1981). "Tristeza" is a phloem restricted disease and most symptoms are associated with phloem damages and its function. The symptoms that CTV causes on citrus fruits depend on the virus strain, type and rootstock combination (Bové et al, 1988).

Infection with mild strains of CTV may not show symptoms on hosts, whereas infection with aggressive strains most often leads to rapid and complete decay of plants (Bar-Joseph et al. 1989). Resistance to most CTV strains has been observed on trifoliate orange (Poncirus trifoliata (L.) Raf), "rough lemon" (Citrus jambhiri Lush.), Rangpur lime (C. limonia Osbeck) and Volkamer lemon (C.s volkameriana Ten. \& Pasq) on which CTV does not cause changes in phloem functionality and they are often used as a rootstock in areas where CTV is a problem (Lee and Bar-Joseph, 2000).

Depending on the virus strain and the scion-rootstock combination, aggressive strains of CTV can cause symptoms of seedling yellows (SY), stem pitting (SP) and rapid tree decay (quick decline-tristeza) (Lee and Bar- Joseph, 2000). Quick decline-tristeza is a syndrome caused by CTV on various types of citrus species grafted onto lemon or sour orange rootstocks (Moreno et al., 2008) (Figure 1). The worst symptom of CTV infection is rapid drying, when the infected tree begins to show wilting symptoms and dies completely within a few weeks (Schneider, 1959). 
Ivana Paladin Soče i sur.: The prospects of development of the citrus production in the Neretva valley in the context of contemporary tendencies

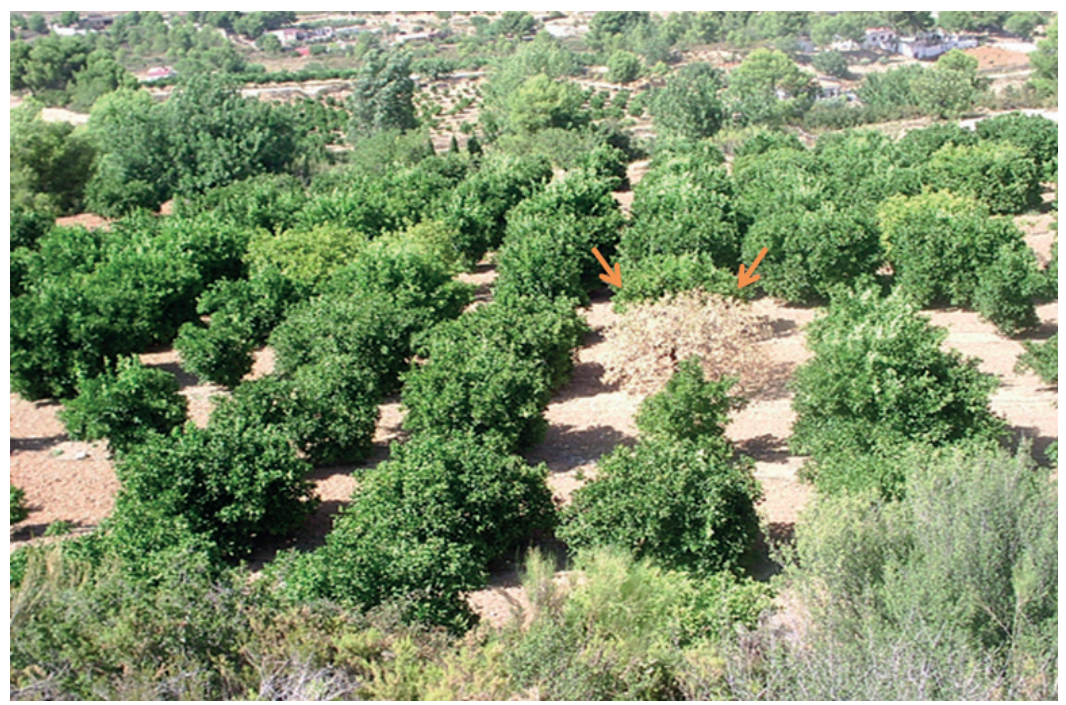

Figure 1 A citrus tree infected with CTV showing quick decline symptoms in the province of Valencia, Spain (Source: R. Montalt, Instituto Valenciano de Investigaciones Agrarias)

Slika 1. Simptomi brzog propadanja stabla quick-decline tristeza virus u provinciji Valencije (izvor: R. Montalt, Instituto Valenciano de Investigaciones Agrarias)

Infection with CTV can also cause tree stunting, which leads to low productivity with the emergence of stem pitting (SP), bumps under the bark of the trunk or shoots (Figure 2) (Lee and Bar-Joseph, 2000). Unlike Tristeza, SP syndrome does not usually cause tree dying, but it can cause chronic decline in productivity and major economic losses (Moreno et al., 2008).

The third syndrome caused by CTV, seedling yellows (SY), is characterized by the stunting of young seedlings (Figure 2). Young, pale or yellow leaves develop, causing a reduction of the root system (Moreno et al., 2008). 
Ivana Paladin Soče i sur.: The prospects of development of the citrus production in the Neretva valley in the context of contemporary tendencies
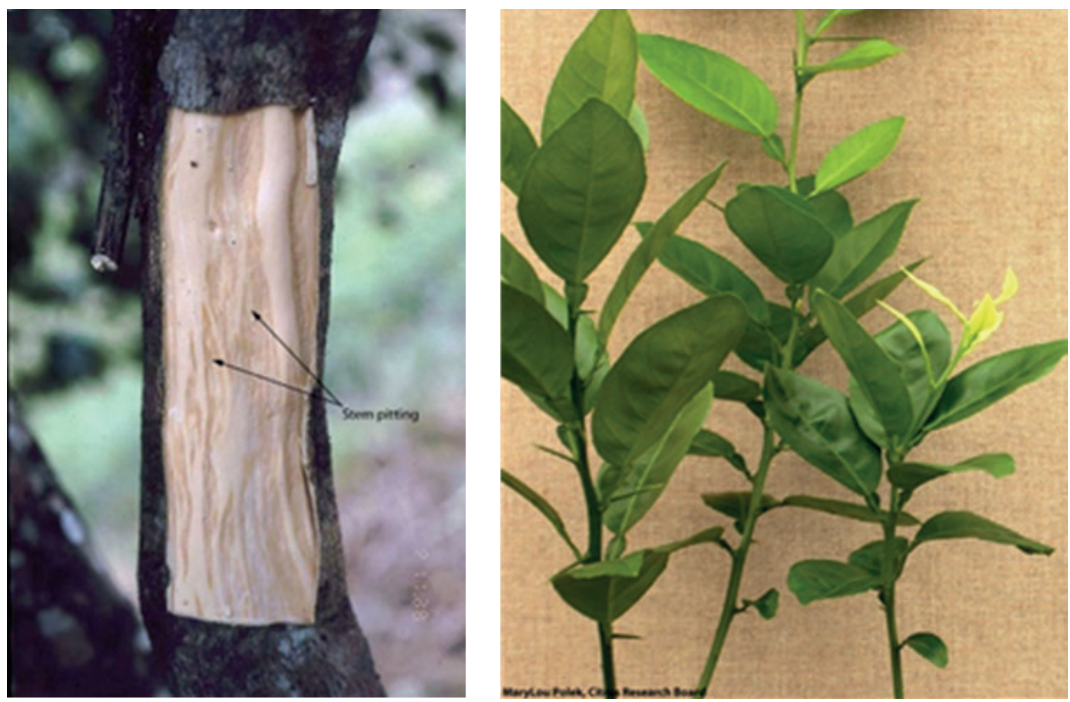

Figure 2 Symptoms of stem-pitting (left) and seedling yellow (right) caused by CTV infections. (Source: http://itp.lucidcentral.org/id/citrus/diseases/key/ Diseases_of_Citrus/Media/Html/Tristeza.htm)

Slika 2. Simptomi jamičavosti (stem-pitting) (lijevo) i žutica sjemenjaka (seedling yellow) (desno) (izvor:http://itp.lucidcentral.org/id/citrus/diseases/key/ Diseases_of_Citrus/Media/Html/Tristeza.htm)

CTV is most commonly transmitted from the infected to the healthy plant by graft transmission, whereas transmission by seed has not been reported (Bar-Joseph et al. 1989). Trading of non-regulated host plants can easily cause CTV spreading to new areas, while aphids are responsible for local spreading of the virus (Wubshet and Amare, 2019). In plantations, CTV is transmitted by aphids in a semipersistent manner (Rocha Peña et al., 1995). The most common CTV vectors are the Black Citrus Aphid Toxoptera citricida Kirkaldy, the Brown Citrus Aphid T. aurantii Boyer de Fonscolombe, the cotton aphid Aphis gossypii Glover and the green citrus aphid A. spiraecola Patch, (Bar-Joseph et al. 1989). Aphids can transmit the virus within at least 24 hours, while virulence is lost after 48 hours (Moreno et al., 2008). 
Ivana Paladin Soče i sur.: The prospects of development of the citrus production in the Neretva valley in the context of contemporary tendencies

\section{CASE STUDY-SPAIN}

Citrus cultivation in Spain has a long history that has been plagued by several serious illnesses that have repeatedly brought the production to the edge of sustainability. The commercial cultivation and exporting of fresh fruits to European countries began at the end of the 19th century leading to rapid growth of citrus production (Navarro et al., 2005). The expansion of commercial farming also had consequences to the production. The first serious problem arose in 1892, when 4,000 ha of citrus plantations along the Mediterranean coast decayed (Navarro, 2015).

The decay was due to root and root collar rot caused by fungal-like-organisms or "pseudofungi" of the Phytophthora genus. Most of the decayed varieties were grafted onto sweet orange $(C$. sinensis $\mathrm{L}$.), lemon $(C$. lemon $\mathrm{L}$.) or grown on their own root, while few were grafted onto sour orange rootstock which is tolerant to this pathogen. It is a well-known fact that sour orange is tolerant to numerous biotic and abiotic factors that made it the most dominant citrus medium worldwide (Navarro, 2015). However, the use of sour orange as a rootstock created the conditions for the development of a new epidemic of the disease which until then was unknown (Moreno et al., 2008). In the early $20^{\text {th }}$ century, citrus grafted onto sour orange had an area of about 18,000 ha (Navarro et al., 2005).

In the period from 1910 to 1930 , new high quality citrus fruits and varieties such as Grapefruit from America and Satsuma mandarins from Japan were imported to Spain and used to raise new plantations with a new variety. Phytosanitary control was not carried out during importation because many viral diseases and other graft-transmissible pathogens were still unknown at the time. Most imported varieties were infected with numerous viruses and viroids, including CTV (Navarro, 2015). It is believed that CTV was introduced in Spain by Sweet orange seedlings (Navel) imported from California (USA) between 1930 and 1935 (Cambra et al., 2000).

The beginning of the CTV epidemic in Spain was recorded in 1957 as a result of the interaction between sensitive varieties and sour orange rootstock (Moreno et al., 2008). The epidemic first appeared in the Valencia province, more specifically in La Ribera Alta (Cambra et al., 2000). The disease spread rapidly within the citrus plantations causing a major epidemic that by 1968 more than 44 million trees grafted onto sour orange had decayed (Navarro, 2015). Most of the affected plantations were located in the province of Valencia with the cultivated areas of Alicante, Castellon and Valencia. According to Cambra et al. (1988) citrus plantations in these areas occupied about 160,000 ha - approx. 64 million trees. Most of the affected plantations were sweet orange and mandarin (C. reticulata Blanco) plantations grafted onto sour orange (Cambra et al. 2000). 
Ivana Paladin Soče i sur.: The prospects of development of the citrus production in the Neretva valley in the context of contemporary tendencies

The Spanish agriculture was seriously threatened in the late 1960s. The risk of socio-economic catastrophe was increasing and in 1968 the competent authorities adopted several legal measures that drastically changed the course of the production (Navarro, 2015). Sour orange rootstock was forbidden for further use and the obligation to produce seedlings on tolerant substrates such as Troyer citrange and Cleopatra mandarin was adopted. In addition, mandatory control measures were introduced at all stages of citrus production, while any import of citrus seedlings was banned (Navarro et al., 2002).

In addition, the legal framework for citrus nursery business was clearly regulated. Nurseries had to be located at least $50 \mathrm{~km}$ from the infestation area, they had to meet the production conditions and the ability to produce at least 300,000 seedlings a year. These measures caused a drastic decrease in the number of nurseries and the number of nurseries with a work permit dropped from a few thousand to only nine (Navarro et al., 2005) which also made it easier to monitor and control the production. By the end of 1972, CTV had covered as much as 82,000 ha (Navarro, 1976) out of 225,000 ha of citrus plantations in the early 1970s (Navarro et al., 2002). (Map view_1.).

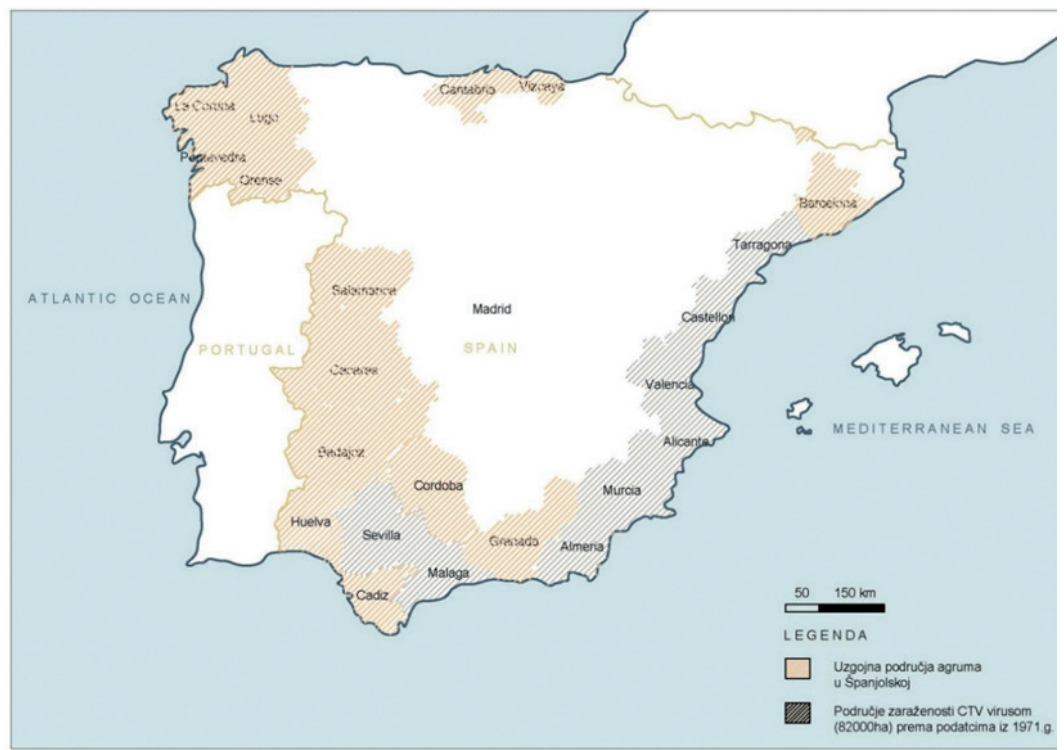

Cartographic view 1 CTV Infection area according to data from 1971, Spain (Prepared by: Mira Medović)

Kartografski prikaz 1. Područje zaraženosti CTV-om prema podacima iz 1971. godine, Španjolska (pripremila: Mira Medović) 
Ivana Paladin Soče i sur.: The prospects of development of the citrus production in the Neretva valley in the context of contemporary tendencies

According to early researches and sampling, it was estimated that viruses and virus-like diseases caused a loss of $10-25 \%$ of the total production in Spain (Navarro et al., 2002). Further laboratory testing of the trees revealed infection with four or more pathogens (Psorosis, Impietratura, Exocortis and Concave gum) which was a turning point for citrus production in Spain.

Shortly after that discovery, and in 1975, the Citrus Variety Improvement Program in Spain (CVIPS) was launched (Navarro, 1976).

The program was based on five goals equally important for obtaining healthy material: (1) obtaining virus-free plants by in vitro micrografting; (2) maintaining healthy genotypes as gene banks; (3) adopting a certification program (4) supplying nurseries with healthy planting material through the certification scheme and (5) the introduction of new varieties through quarantine (Navarro et al., 2002).

The responsibility for implementing CVIPS in the scientific and technological aspects of the certification process, was taken over by the Agricultural Research Center - IVIA (Instituto Valenciano de Investigaciones Agrarias) (Anonymous, 2016). The program has been in place since 1978 when the first healthy shoot tip grafting (STG) plants were distributed to nurseries. Nurseries began selling healthy plants in 1982 and among the first seedlings were the Navelate, Navelina and Newhall navel oranges, Clausellina Satsum mandarin and Verna and Fino lemons (Navarro et al., 1980).

Spatial and temporal research on the spread of CTV continued in the following years. Until 1986, the geographical spread of CTV was based on visual inspections in plantations; however, these data were incomplete as infected trees can be symptomless. Thus, in early 1986, the first study on the spread of CTV in Spain was conducted by the ELISA test using specific CTVmonoclonal antibodies (Cambra et al., 1988). The highest percentage of infection was found in Valencia. CTV was confirmed in more than $75 \%$ of the trees surrounding the area $(0,6 \%$ area). Among the infected trees, as many as $80 \%$ referred to Satsuma mandarins that showed no symptoms in the plantation (Cambra et al. 1988). Using the DAS-ELISA test, all destructive strains in the plantations were identified and the Spanish Ministry of Agriculture, according to the legal regulations of July 30,1986, ordered removing all trees with aggressive strains according to a program implemented by the Central California Tristeza Eradication Agency - (CCTEA). Only those trees that were found to be CTV positive in two independent tests were removed (Cambra et al., 1993). According to the program, after the eradication of infected trees grafted onto sour orange, each newly planted tree in that plantation was 
Ivana Paladin Soče i sur.: The prospects of development of the citrus production in the Neretva valley in the context of contemporary tendencies

inspected annually and all additional infected trees were removed later (Dodds et al, 1996). An eradication program was issued in the territory of Valencia Community which obliged producers to declare the areas where early Satsuma assortment was propagated in order to monitor their health. There was a zerotolerance rate for the presence of aggressive isolates of CTV - it required the destruction of entire plantations, but with one essential measure - compensation for damage to the owner. By 1991, as many as $80 \%$ of propagated seedlings of Satsuma cultivars had been destroyed (Roistacher and Moreno, 1991).

Researches on the spread of CTV in the municipality of Valencia (Graph 1) were carried out from the beginning of 1989 till 1998. A total of 96,000 trees were tested and the spread of CTV grew gradually. The reason for the spread were aphids, especially $A$. gossypi, which became a highly dominant species in that part of Spain (Cambra et al., 2000)

— 1989 - 1995

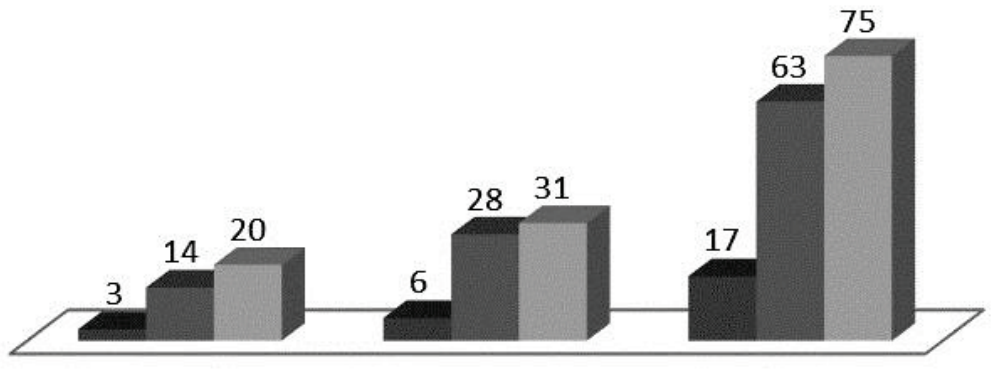

Alicante

Castellon

Valencia

Graph 1 Frequency of the presence of CTV (\%) in Valencia in 1989, 1995 and 1998 (Cambra et al., 2000)

Graf 1. Učestalost otkrivanja CTV-a (\%) u provinciji Valenciji u 1989., 1995. i 1998. godini (Cambra i sur., 2000.)

The implemented measures resulted in progressive and systematic replacement of trees decayed due to CTV in main citrus plantations in Spain and today more than 160 million certified citrus trees have been planted (Anonymus, 2019) covering 330,000 ha with an average production of 7 million tonnes per year. Most plantations are occupied by sweet orange $48 \%$, mandarin $35 \%$ and lemon $16 \%$. They are mostly grafted onto Carrizo or Troyer citrange (Navarro et al., 2002). 
In addition, Spain is today considered the largest producer of citrus fruits and citrus juice in the European Union and one of the largest exporters of fresh fruit with more than $50 \%$ of its production. The majority of production concerns oranges (Navarro, 2015). The citrus plantations are mainly located along the Mediterranean coast in the provinces of Tarragona, Castellon, Valencia, Murcia, Almeria and Malaga in the provinces of Seville and Cordoba and on the Atlantic coast in the province of Huelva (map view_2.)

Due to the adoption of the certification program and the systematic approach, Spain has experienced a recovery in citrus fruit and a decrease in the percentage of CTV infections (EFSA, 2017). The only serious threat that can threaten citrus production is the accidental introduction of new fungal and bacterial diseases (Pina et al., 2015).

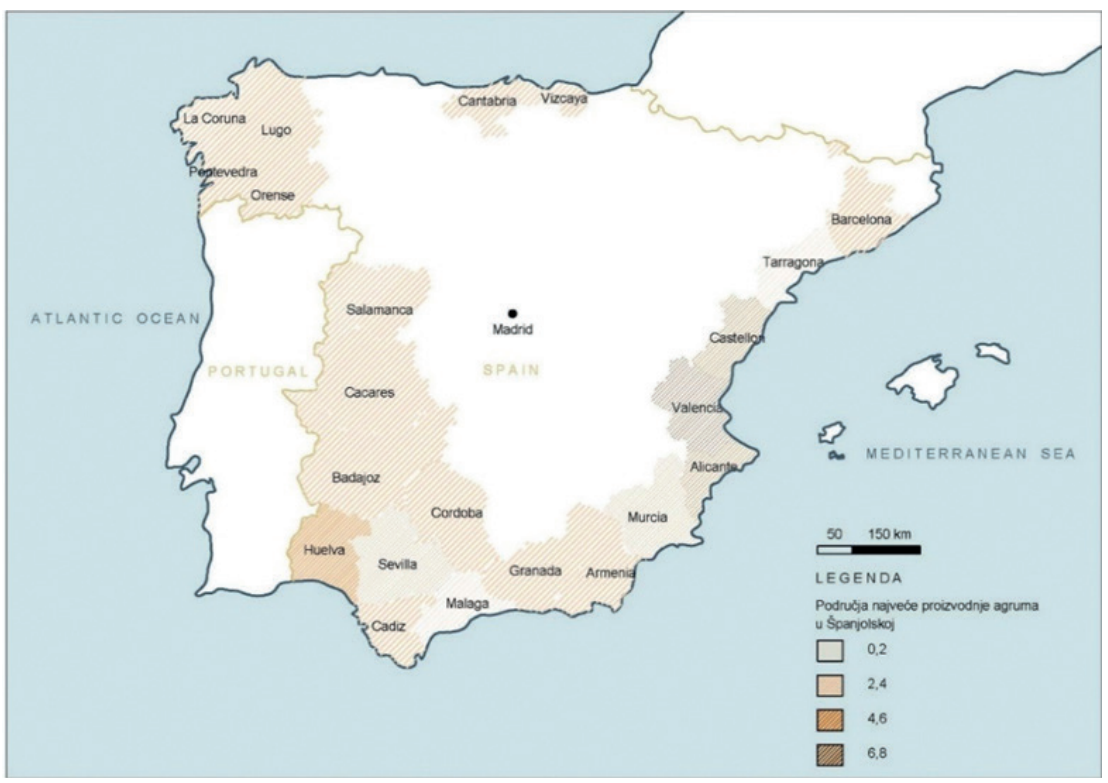

Cartographic Map 2 Citrus growing areas in Spain (Source: Evaluation of new scientific information on Phyllosticta citricarpa in relation to EFSA PLH Panel (2014) EFSA 2016; Prepared by: Mira Medović)

Kartografski prikaz 2. Područja uzgoja agruma u Španjolskoj (izvor: Evaluation of new scientific information on Phyllosticta citricarpa in relation to the EFSA PLH Panel (2014.) EFSA 2016; Pripremila: Mira Medović) 
Ivana Paladin Soče i sur.: The prospects of development of the citrus production in the Neretva valley in the context of contemporary tendencies

\section{CITRUS PRODUCTION IN CROATIA}

The Neretva Valley is the largest and most economically important cultivation area of citrus in Croatia. About $90 \%$ of the valley is related to cultivation along the lower course of the Neretva River (Ivić et al., 2014). The arable land is mostly occupied by the Japanese Unshiu mandarin while the cultivation of other citrus fruits is restricted due to low temperatures (Marić and Paladin, 2017). In other areas of Croatia, citrus cultivation has been reduced due to inappropriate land, lack of water and low temperatures during winter (Marić and Paladin, 2017). According to the Croatian Bureau of Statistics (2018), the total area under intensive citrus production throughout Croatia is 1.974 ha, of which 1.480 ha are commercial plantations in the Dubrovnik-Neretva County, (Apprrr 2019). The total production of the main citrus species in 2018 was $55,037 \mathrm{t} /$ ha (Table 1).

Table 1 Citrus areas and production in 2018 in Croatia (source: Central Bureau of Statistics, 2018)

Tablica 1. Površine i proizvodnja agruma 2018 godine (izvor: Državni zavod za statistiku, 2018.)

\begin{tabular}{|l|c|c|}
\hline \multicolumn{1}{|c|}{ SPECIES } & INTENSIVE PLANTATIONS (ha) & PRODUCTION (t/ha) \\
\hline LEMON & 33 & 229 \\
\hline ORANGE & 31 & 368 \\
\hline MANDARIN & 1,910 & 47,440 \\
\hline TOTAL & $\mathbf{1 , 9 7 4}$ & $\mathbf{5 5 , 0 3 7}$ \\
\hline
\end{tabular}

One of the biggest problems of CAC category of seedlings production is the infection with CTV (Ivic, 2012). According to Černi et al. (2009a), CTV in Croatia was first mentioned in the work of Davin and Catherine (1986). In their paper, they confirmed their discovery of a virus in the parent plantation of Satsuma mandarins, whose seedlings were introduced to Croatia in the early 80's from Japan. In citrus plantations throughout the Neretva Valley, most of the Satsuma mandarin trees were propagated solely from the aforementioned material and there were no visible symptoms in the plantations. The reason for the invisible symptoms of CTV on citrus trees was attributed to the use of the Poncirus trifoliate rootstock and no particular attention was paid to CTV.

Sarić and Dulić (1990) state that the presence of CTV in native trees during the 1980s was verified by bio-indexing and serological tests. Due to the wartime events of the early 1990s and the collapse of the PIK "Neretva", a systematic 
Ivana Paladin Soče i sur.: The prospects of development of the citrus production in the Neretva valley in the context of contemporary tendencies

check on the health status of citrus planting material in Croatia had largely gone. This paper reports on the testing of citrus stem trees in the Neretva valley during 1986 and 1988, where the majority of Mandarin cultivars (Kuno, Okitsu, Wakiyama, Kawano Wase and Owari) were infected with CTV. These cultivars were mostly introduced from Japan and Georgia between 1965 and 1984.

A program for special monitoring of the CTV was implemented in Croatia in 2005. The program was implemented by the Centre for Plant Protection, formerly the Croatian Centre for Agricultural Food and Rural Affairs (HCPHS), today the Agency for Agriculture and Food (HAPIH). In 2005, a total of 57 samples were analysed by the program of special monitoring of citrus fruits in the Neretva valley and CTV was confirmed in 42 samples ( $74 \%$ infection rate)

In 2006, 108 samples were analysed from Dubrovnik Neretva valley and as many as 86 were positive (80\%). In other localities in the Split-Dalmatia and the Dubrovnik-Neretva counties, CTV was detected in 22 out of 60 tested samples (37\%) (Ministry of Agriculture in Croatia, 2006).

A significant contribution to the knowledge of CTV in Croatia was provided by Černi et al. (2009a). Independently of the special monitoring program of the Ministry of Agriculture, a total of 45 samples of different citrus trees were tested from 11 localities in Croatia (4 nurseries in Vis, 3 nurseries in Opuzen and 1 nursery in each of Kaštel Štafilić, Kaštel Nehaj, Brač and Metković). CTV was confirmed in 17 citrus trees collected from Vis, Opuzen, Kaštela and Brač. About $38 \%$ of the trees were CTV-positive, furthermore, only 3 trees showed symptoms that could be attributed to the infection with Exocortis viroid. Černi et al. (2009b) published another scientific paper in which they studied the genetic variability of CTV in 16 isolates taken from Croatia and other 3 isolates collected from Montenegro and Albania. Molecular analysis showed that aggressive stem-pitting strains of CTV were found in Croatia and finally they noted that the Adriatic coast was an accumulation area of different CTV genotypes.

The program of special monitoring of the Ministry of Agriculture continued in 2010. Laboratory analyses were carried out within the Institute for Plant Protection and the analyses included 131 samples of which 16 samples were positive on CTV (12\%) (Ivić et al., 2014).

Furthermore, in the coming years between 2014 and 2019, other tests on citrus trees were carried out in the Neretva valley. In general, laboratory analyses on the presence of CTV in the Neretva Valley have been carried out since 2005. A slight decrease in CTV infection can be noticed in graph 2. which summarizes CTV incidences in the Neretva Valley in 2005, 2006, 2010 and from 2014 to 2019, according to data provided from the Ministry of Agriculture. 
Ivana Paladin Soče i sur.: The prospects of development of the citrus production in the Neretva valley in the context of contemporary tendencies

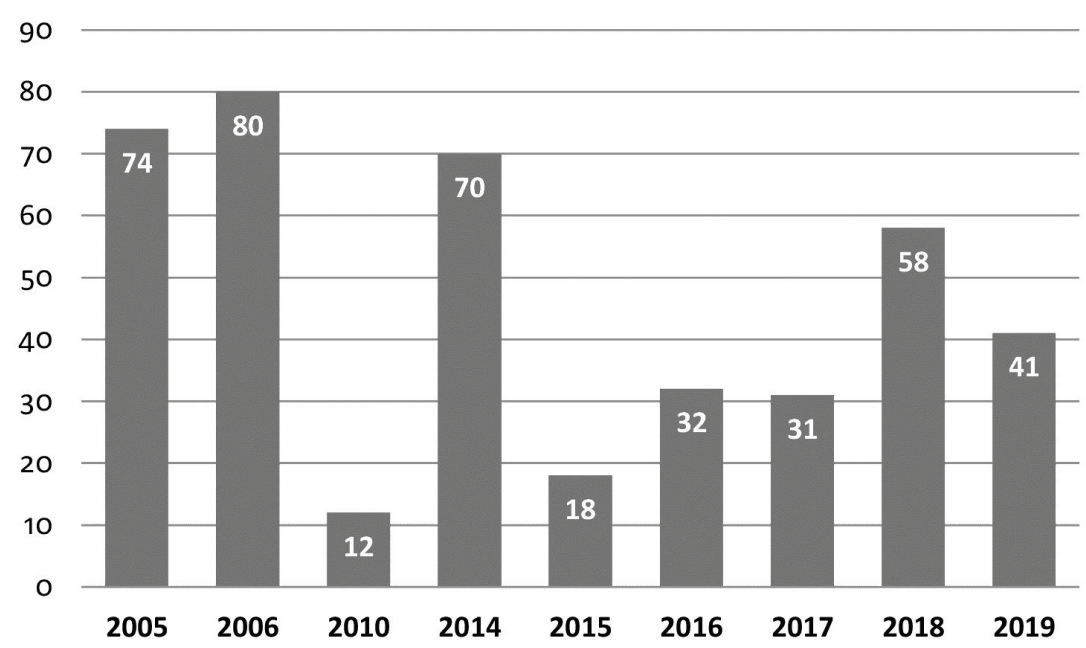

Graph. 2 Incidence of CTV infections in the Neretva Valley (2005-2019). The incidence number for each year is written inside each blue bar.

Graf. 2. Rezultati praćenja raširenosti CTV-a plantažnim nasadima u dolini Neretve (2005-2019.godine)

In order to facilitate the production of planting material and enable export to other EU countries, the existing citrus production system needs to be updated by establishing a certification scheme. An important step in establishing a certification scheme is to modernize the complete production of citrus fruits, that is, to establish high-grade nurseries.

\section{CONCLUSION}

Important steps in establishing a certification program for citrus production in the Republic of Croatia have been undertaken by the Ministry of Agriculture of the Republic of Croatia together with the Institute for Plant Protection, Croatian Agency for Agriculture and Food (HAPIH). One of these steps is the adoption of the ordinance on placing reproductive planting material and seedlings intended for fruit production on the market (OG 9/17), a systematic control program and the important Project "Raising the quality of citrus nurseries" carried out by the Institute of Mediterranean Crops, University of Dubrovnik. There are several important aspects from the Spanish experience that can be applied in the Neretva Valley to reduce CTV infection for successful virus control: 
Ivana Paladin Soče i sur.: The prospects of development of the citrus production in the Neretva valley in the context of contemporary tendencies

- Use of CTV resistant rootstocks.

- Application of strict quarantine measures to avoid any CTV-infected plant materials to be bought into the Republic of Croatia;

When importing fruits from infested countries, they should be either free from leaves and peduncles, washed and waxed;

Continuing CTV surveys to detect any new outbreaks in Croatia where the virus is not present, or to detect the presence of any CTV severe strains;

- Vector control in plantations using insecticides;

- Prohibition of taking buds or any plant materials for propagation from infected citrus trees;

- Legal provisions authorizing the exploitation of infected citrus fruits In addition, it is necessary to eradicate old citrus plantations grafted on sour orange and to eradicate citrus trees with aggressive CTV strains, i.e. to fully comply with the certification scheme.

Regarding legislation, the Spanish example shows a large range of financial sanctions for citrus planters who do not comply with the set legal standards. The minimum financial penalty of $300 €$ relates to a breach of obligations to the competent authorities, statutory deadlines and a breach of the obligation to exercise independent control within one's own plantation. The maximum statutory fine is $300,000 €$ and refers to offenses in the form of falsification of variety data, material category or plant health (Ley 30/2006).

The example of eradication in Spain shows that by applying all these measures, it is possible to establish healthy citrus plantations and to reduce $\mathrm{CTV}$ infection to the minimum, i.e. to harmonize production with the highest standards inherent in other EU countries, which is the goal to be achieved in Croatia.

\section{BIBLIOGRAPHY}

BAKARIĆ, P. (1983): Uzgoj mandarine Unšiju, Stanica za južne kulture, Dubrovnik

BAR-JOSEPH, M., MARCUS, R., LEE, R.F. (1989): The continous challenge of citrus tristeza virus control. Annual Review of Phytopathology 27, 291-316.

BOVÉ, C., VOGEL, R., ALBERTINI, D. AND BOVÉ, J.M. (1988): Discovery of a strain of tristeza virus inducing no symptoms in Mexican lime, Proceeding of the 10th International Organization of Citrus Virologists IOCV,pp 14-21, Riverside, CA. 
Ivana Paladin Soče i sur.: The prospects of development of the citrus production in the Neretva valley in the context of contemporary tendencies

CAMBRA, M., CAMARASA, E., GORRIS, M.T., GARNSEY, S.M., GUMPF, D.J., TSAI, M.C., (1993): Epitope diversity of isolates of citrus tristeza virus (CTV) in Spain, Proceedings of the $12^{\text {th }}$ International Conference Organ Citrus Virology, IOCV. Riverside, pp. 33-38.

CAMBRA, M., GORRIS, M.T., MARROQUÍN, C., ROMÁN, M.P., OLMOS, A., MARTÍNEZ, P.C., HERMOSO DE MENDOZA, A.H., LÓPEZ, A. AND NAVARRO, L. (2000): Incidence and epidemiology of citrus tristeza virus in the Valencian Community of Spain. Virus Res 71, pp 85-95.

CAMBRA, M., SERRA, J., VILLALBA, D., MORENO, P., (1988): Present situation of the citrus tristeza virus in the Valencian Community, Proceedings of the $10^{\text {th }}$ International Conference Organ Citrus Virology, pp 1-7, IOCV, Riverside

ČERNI, S., KRAJAČIĆ, M., HARTL, D., GATIN, Z., ŠKORIĆ, D. (2009a): Presence of Citrus tristeza virus in Croatia. Options Méditerranéennes: Série B, Etudes et Recherches, 65, 89-92.

ČERNI, S., ŠKORIĆ, D., RUŠČIĆ, J., KRAJAČIĆ, M., PAPIĆ, T., DJELOUAH, K., NOLASCO, G. (2009b): East Adriatic - a reservoir region of severe Citrus tristeza virus strains. European Journal of Plant Pathology 124, 701-706.

DODDS, J.A., RILEY, K., POLEK M. (1996): Effect of Suppressionby Tree Removal on the Incidence of Citrus Tristeza Virus in California; Thirteenth ZOCV Conference- Citrus Tristeza Virus; pp. 168-172

EFSA (2017): Pest categorisation of Citrus tristeza virus (non-European isolates), EFSA Journal

IVIĆ D., KAJIĆ V., MILANOVIĆ J., FAZINIĆ T., BUDNIŠĆAK Ž. (2012): PPV i CTV - karantenski virusi u matičnim nasadima Hrvatske. Zbornik sažetaka 56. seminara biljne zaštite, Glasilo biljne zaštite 12, p. 56-57, Opatija

IVIĆ, D., BJELIŠ, M., KRIŽANAC, I. (2014): Stručna podloga za prijedlog programa posebnog nadzora „Karantenski štetni organizmi agruma“ (Citrus tristeza virus, Spiroplasma citri Saglio et al., Phoma tracheiphila (Petri) Kantschaveli \& Gikachvili), Zavod za zaštitu bilja - Hrvatski centar za poljoprivredu, hranu i selo

IVIĆ, D., FAZINIĆ T. (2011): Certifikacijske sheme za proizvodnju sadnog materijala značajnih voćnih vrsta u Hrvatskoj, Pomologia Croatica 1-2, p. 3136 
Ivana Paladin Soče i sur.: The prospects of development of the citrus production in the Neretva valley in the context of contemporary tendencies

KALEB, M. (2014): Razvoj uzgoja mandarina i ostalih agruma u dolini Neretve, Agronomski glasnik br. 4-5, p. 219- 238

LEE, R.F., BAR-JOSEPH, M. (2000). Tristeza. Compendium of Citrus Diseases, Timmer, APS Press, SAD, 61-63

MARIĆ, M., PALADIN, I.,(2017): Podizanje kvalitete matičnih nasada agruma u Republici Hrvatskoj, Pomologia Croatica, vol 21, br 1-2, pp: 71-90

MINISTARSTVO POLJOPRIVREDE (2005-2019): Karantenske štetočinje na citrus vrstama: južnoafrički trips citrusa (Scirtothrips aurantii Faure), crni štitasti moljac citrusa (Aleurocanthus woglumi Ashby), mediteranska voćna muha (Ceratitis capitata Wied.), Citrus tristeza closterovirus (CTV) - tristeza i rak citrusa (Xanthomonas axonopodis pv. citri)

MORENO, P., AMBRÓS S., ALBIACH-MARTÍ M.R., GUERRI J., PEÑA L., (2008): Citrus tristeza virus: a pathogen that changed the course of the citrus industry; Molecular plant pathology 9(2), pp. 251-268

NAVARRO L., (1976): The Citrus Improvement Program in Spain, Proc. 7th Conference IOCV, p. 198-203. IOCV, Riverside, CA

NAVARRO L., (2015): The Spanish Citrus industry, Proc. XIIth Intl. Citrus Congress, Acta Hort 1065. pp 41- 47

NAVARRO, L., BALLESTER, J.F., JUÁREZ, J., PINA, J.A., ARREGUI, J.M., BONO, R., ORTEGA, C. (1980): The Citrus Variety Improvement Program in Spain (CVIPS) after Four Years, International Organization of Citrus Virologists Conference Proceedings (1957-2010), California, pp.289-29

NAVARRO, L., NAVARRO, A., DURÁN VILA, N., GUERRI, J., P. MORENO, P., CAMBRA, M., PINA, J.A., JUÁREZ, J., ARREGUI, J.M., ORTEGA, C., BALLESTER, J.F., CARMEN VIVES, M., MONTALT, R.,. MEDINA, A., ZARAGOZA ADRIAENSENS, S.(2005): El programa de mejora sanitaria de variedades de citricos en Espana: 30 anos de historia, Phytohemeroteca 170, Valencia

NAVARRO, L., PINA, J.A., JUÁREZ J., BALLESTER-OLMOS J.F., ARREGUI, J.M., ORTEGA C., NAVARRO A., DURÁN VILA, N., GUERRI, J., MORENO, P., CAMBRA, M., MEDINA, S., ZARAGOZA, S., (2002): The Citrus Variety Improvement Program in Spain in the Period 1975-2001; Fifteenth IOCV Conference, pp. 306-316 
Ivana Paladin Soče i sur.: The prospects of development of the citrus production in the Neretva valley in the context of contemporary tendencies

PINA, J.A., PEDRO CHOME, P.,2, VIVES, MC., NAVARRO, L.,(2015): The Citrus Nursery Tree Certification Program in Spain, Proc. XIIth Intl. Citrus Congress, pp.745-752

ROCHA PEÑA, M.A., LEE, R.F., LASTRA, R., NIBLETT, C.L., OCHOA CORONA, F.M., GARNSEY, S.M., YOKOMI, R.K. (1995): Citrus tristeza virus and its aphid vector Toxoptera citricida, Plant Disease 79, 437-445

ROISTACHER, C.N. (1981): A blueprint for disaster- The history of seedling yellows disease. Citrograph , 67, 4-24.

ROISTACHER, N., MORENO P. (1991): The Worldwide Threat from Destructive Isolates of Citrus Tristeza Virus-A Review; International Organization of Citrus Virologists Conference Proceedings (1957-2010)

SCHNEIDER, H. (1959): The anatomy of tristeza-virus-infected citrus, Citrus Virus Diseases, University of California, pp. 73-84. Berkeley, CA

WUBSHET Z. I AMARE D., (2019): Review on Citrus Triteza Virus, International Journal of Research Studies in Agricultural Sciences (IJRSAS), vol.5, pp:25-36

JEFATURA DE ESTADO (2006): Ley 30/ 2006 de 26 de julio, de semillas y plantas de vivero y de recursos fitogenéticos

MÜLLER, G.W., COSTA, A.S., KITAJIMA, E.W., CAMARGO, I.J.B. (1974). Additional evidence that tristeza virus multiplies in Passiflora spp. In Proceedings of the $6^{\text {th }}$ Conference of the International Organization of Citrus Virologists - IOCV. Riverside, EUA. p. 75-78

\section{Authors address - Adresa autora:}

Ivana Paladin Soče, e-mail: ivana.paladin@unidu.hr, Mara Marić

Zavod za mediteranske kulture, Sveučilišta u Dubrovniku, Ulica Branitelja Dubrovnika 29, 20000 Dubrovnik

Dario Ivić,

Centar za zaštitu bilja, Hrvatska agencija za poljoprivredu i hranu, Gorice 68B, 10000 Zagreb 